\title{
Aromatherapy for Laboring Women: A Meta-Analysis of Randomized Controlled Trials
}

\author{
Taizhen Luo ${ }^{1}$, Meiling Huang², Huaan Xia', Yingchun Zeng1 \\ ${ }^{1}$ Department of Obstetrics, The Third Affiliated Hospital of Guangzhou Medical University, Guangzhou, China \\ ${ }^{2}$ Department of Nursing, The Third Affiliated Hospital of Guangzhou Medical University, Guangzhou, China \\ Email: ${ }^{\text {596830447@qq.com }}$
}

Received 29 November 2013; revised 26 January 2014; accepted 26 February 2014

Copyright (C) 2014 by authors and Scientific Research Publishing Inc.

This work is licensed under the Creative Commons Attribution International License (CC BY). http://creativecommons.org/licenses/by/4.0/

c) (7) Open Access

\begin{abstract}
Aromatherapy is the therapeutic use of oil from herbs, flowers, and other plants. The aim of this meta-analysis was to quantify the effectiveness of aromatherapy for laboring women. We searched five electronic databases till November 15th 2013 including those Chinese and English language articles. A total of 4 eligible studies were identified. Aromatherapy was effective in reducing the length of labor, but there were no statistically significant effects in the use of pharmacological analgesia, spontaneous vaginal delivery, caesarean delivery and assisted vaginal birth. Due to the limited number of articles identified, the evidence is not sufficiently convincing that aromatherapy is an effective therapy for laboring women.
\end{abstract}

\section{Keywords}

Aromatherapy; Laboring Women; Randomized Controlled Trials; Meta-Analysis

\section{Introduction}

Labor presents a physiological and psychological challenge for women [1]. Childbirth is arguably one of the most painful experiences and the most significant physical challenge for women to undergo during their lives [2]. Pain is caused by uterine contractions, cervical dilatation, and vaginal and pelvic floor stretching to accommodate the baby [1] [3]. Psychological challenges include tension, anxiety and fear, which are factors contributing towards women's perception of pain and may also affect their labor and birth experience [1].

Women increasingly use complementary therapies as a means of retaining control over their childbearing ex-

"Corresponding author. 
periences and as additional choices for managing antenatal symptoms and intrapartum comfort and progress [4]. Nowadays, using alternative and complementary therapies such as essential oils in aromatherapy has been recognized in obstetrics [5]. Aromatherapy involves the use of the essential oils from herbs, flowers, and other plants [6]. The oils may be massaged into the skin, or inhaled by using a steam infusion or burner. The most common application of aromatherapy during labor is by massage, bath or inhalation [7].

Due to the increasing popularity of application of aromatherapy for laboring women, the aim of this study was to examine the effects of aromatherapy on the delivery outcomes of laboring women through systematic review and meta-analysis.

\section{Methods}

Five databases (Medline, CINAHL, Scopus, The Cochrane Library, and CAJ Full-text Database) were searched until November 15, 2013, and articles published in English and Chinese were included in the data sample. The search terms included "aromatherapy", "labor", "delivery”, and "intrapartum midwifery practice”. Eligible studies were randomized controlled trials (RCTs), eligible types of participants were women in labor, and types of interventions included the use of any type of aromatherapy for labouring women.

For each study included, data were extracted from the original paper independently by one of the main researcher and then verified by another researcher. Disagreements concerning data extraction were resolved by discussion. Trial quality was judged based on five domains: random sequence generation, allocation concealment, assessor blinding, patient blinding, and incomplete outcome data (Table 1). The Cochrane Collaboration's Review Manager (RevMan 5.2) was used to generate pooled estimates of effect size.

\section{Table 1. Summary of the 4 clinical trials of aromatherapy for women in labor.}

\begin{tabular}{|c|c|c|c|c|c|c|}
\hline Trials & Participants & Intervention & Comparison & Main outcome & $\begin{array}{l}\text { Study } \\
\text { design }\end{array}$ & $\begin{array}{l}\text { Risk of } \\
\text { bias }\end{array}$ \\
\hline $\begin{array}{l}\text { Burns et al. } \\
\qquad[8]\end{array}$ & $\begin{array}{l}513 \text { women with } \\
\text { a singleton } \\
\text { pregnancy }\end{array}$ & $\begin{array}{l}\text { The experimental } \\
\text { group received } \\
\text { aromatherapy. } \\
\text { Modes of application } \\
\text { included acupressure } \\
\text { points, taper, } \\
\text { compress, footbath, } \\
\text { massage or birthing } \\
\text { pool. }\end{array}$ & $\begin{array}{l}\text { The control } \\
\text { group } \\
\text { received usual } \\
\text { care. }\end{array}$ & $\begin{array}{c}\text { Pain intensity (only } \\
\text { aromatherapy group), assisted } \\
\text { vaginal birth, caesarean } \\
\text { section, use of } \\
\text { pharmacological pain relief, } \\
\text { spontaneous vaginal delivery, } \\
\text { length of labour, } \\
\text { augmentation, and perineal } \\
\text { trauma. }\end{array}$ & $\begin{array}{c}\text { RCT, } \\
\text { Parallel }\end{array}$ & $\mathrm{Y}, \mathrm{Y}, \mathrm{N}, \mathrm{N}, \mathrm{Y}$ \\
\hline $\begin{array}{l}\text { Calvert et al. } \\
\text { [9] }\end{array}$ & $\begin{array}{c}22 \text { multiparous } \\
\text { women with a } \\
\text { singleton } \\
\text { pregnancy. Women } \\
\text { were recruited } \\
\text { during the } \\
\text { antenatal period }\end{array}$ & $\begin{array}{l}\text { The experimental } \\
\text { group received } \\
\text { essential oil } \\
\text { of ginger for the bath } \\
\text { at least } 1 \text { hour. }\end{array}$ & $\begin{array}{c}\text { The control } \\
\text { group received } \\
\text { essential oil of } \\
\text { lemon grass for } \\
\text { the bath at least } \\
1 \text { hour. }\end{array}$ & $\begin{array}{c}\text { Pain intensity (only } \\
\text { aromatherapy group), } \\
\text { assisted vaginal birth, } \\
\text { caesarean section, use of } \\
\text { pharmacological pain relief, } \\
\text { spontaneous vaginal delivery, } \\
\text { length of first and second stage } \\
\text { of labour, frequency of } \\
\text { contractions, and cervical } \\
\text { dilatation. }\end{array}$ & $\begin{array}{c}\text { RCT, } \\
\text { double-blind }\end{array}$ & Y,Y,Y,Y,Y \\
\hline $\begin{array}{c}\text { Vakilian \& } \\
\text { Keramat } \\
{[10]}\end{array}$ & $\begin{array}{c}120 \text { primiparous } \\
\text { women planning } \\
\text { a vaginal delivery }\end{array}$ & $\begin{array}{l}\text { Essential oil of } \\
\text { lavender with } \\
\text { breathing } \\
\text { technique via } \\
\text { nebuliser during } \\
\text { contractions in the } \\
\text { active phase of labour }\end{array}$ & $\begin{array}{c}\text { Breathing } \\
\text { techniques } \\
\text { without } \\
\text { aromatherapy }\end{array}$ & $\begin{array}{l}\text { Duration of the first phase and } \\
\text { the second stage of labour. }\end{array}$ & $\begin{array}{l}\text { RCT, single } \\
\text { blinded }\end{array}$ & $\mathrm{Y}, \mathrm{Y}, \mathrm{N}, \mathrm{N}, \mathrm{Y}$ \\
\hline $\begin{array}{c}\text { Zahra \& Leila } \\
\quad[11]\end{array}$ & $\begin{array}{c}60 \text { primiparous } \\
\text { women planning } \\
\text { a normal delivery }\end{array}$ & $\begin{array}{c}\text { Aromatherapy } \\
\text { massage with } \\
\text { Lavender oil }\end{array}$ & $\begin{array}{l}\text { Receiving } \\
\text { massage only }\end{array}$ & $\begin{array}{l}\text { Pain, duration of the first } \\
\text { phase and the second \& third } \\
\text { stages of labour. }\end{array}$ & RCT & $\mathrm{Y}, \mathrm{Y}, \mathrm{N}, \mathrm{N}, \mathrm{Y}$ \\
\hline
\end{tabular}

Risk of bias (sequence generation, allocation concealment, assessor blinding, patient blinding, description of incomplete outcome data); Y, Yes; N, No; RCT, Randomized Controlled Trial. 


\section{Results}

\subsection{Description of Included Studies}

A total of 4 RCTs were included in this review. The selection of studies is shown in Figure 1. Of these 4 trials, one trial [8] compared aromatherapy intervention with usual care. Three [9]-[11] adopted aromatherapy as study interventions, and used other active interventions including other types of aromatherapy, breathing techniques and massage as control. The characteristics of these 4 trials are summarized in Table 1.

\subsection{Effects of Aromatherapy Intervention}

Four RCTs with a total of 715 subjects included in this review, these 4 studies reported enough data to generate pooled estimates of effect size of aromatherapy for the delivery outcomes of laboring women.

\subsubsection{Effects on Using of Pharmacological Analgesia}

Two studies [8] [9] examined the effects of aromatherapy on the use of epidural analgesia among laboring women. Graph 1 shows that there was no difference seen between the aromatherapy group and the control group in their use of epidural analgesia (Risk Ratio $-\mathrm{RR}=0.97,95 \% \mathrm{CI}=0.14$ to 6.57, two trials, 535 subjects).

\subsubsection{Effects on Spontaneous Vaginal Delivery}

Two studies [8] [9] examined the effects of aromatherapy on the rate of spontaneous vaginal delivery among laboring women. From Graph 2, there was no difference in vaginal delivery between the aromatherapy group and the control group $(\mathrm{RR}=1.00,95 \% \mathrm{CI}=0.94$ to 1.06 , two trials, 535 subjects).

\subsubsection{Effects on Assisted Vaginal Birth}

Two studies [8] [9] examined the effects of aromatherapy on the rate of assisted vaginal birth among laboring women. From Graph 3, there was no difference with assisted vaginal birth between the aromatherapy group and the control group ( $\mathrm{RR}=1.03,95 \% \mathrm{CI} 0.48$ to 2.17 , two trials, 535 subjects).

\subsubsection{Effects on Caesarean Delivery}

Two studies [8] [9] examined the effects of aromatherapy on the rate of caesarean delivery among laboring women. From Graph 4, there was no difference in caesarean section between the aromatherapy group and the control group ( $\mathrm{RR}=1.02,95 \%$ CI 0.53 to 1.99 , two trials, 535 subjects).

\subsubsection{Effects on Length of Labor}

From Graph 5, there were statistically significant differences in reduction of labor length. For the active phase of labor (Weighted Mean Difference-WMD $=-1.38,95 \% \mathrm{CI}=-2.37$ to -0.40 , two trials, 180 subjects). For the second stage of labor, the WMD was -12.74 ( $95 \%$ CI $=-16.46$ to -9.03 , two trials, 180 subjects).

Although there were no enough data for statistically pooling for estimating the effect size of aromatherapy in pain reduction, one trial found that women following aromatherapy reported reduction of pain in the latent and active phase of labor (all p values $=0.0001$ ) [11]. This trial also reported on the outcome of satisfaction with childbirth experience and found that women in the aromatherapy group had higher level of satisfaction of childbirth experience than women in the control group $(\mathrm{p}=0.014)$ [11]. There were no adverse outcomes of aromatherapy reported among these four studies.

\section{Discussion}

These 4 trials mainly reported the effect of aromatherapy on the physical health outcomes of laboring women. In terms of the delivery mode of aromatherapy, this study found aromatherapy was commonly delivered with massage or bath therapy. Due to the nature of aromatherapy intervention, it may be difficulty in blinding participants and intervention delivery. But no trials attempted to blind the outcome assessors to minimize the potential methodological bias. Therefore, a risk of biases might be introduced in these 4 trials.

Although there is an increasing interest in use of aromatherapy in healthcare [12], there were limited numbers of RCTs of aromatherapy for laboring women. While the use of aromatherapy indicates positive findings in re- 


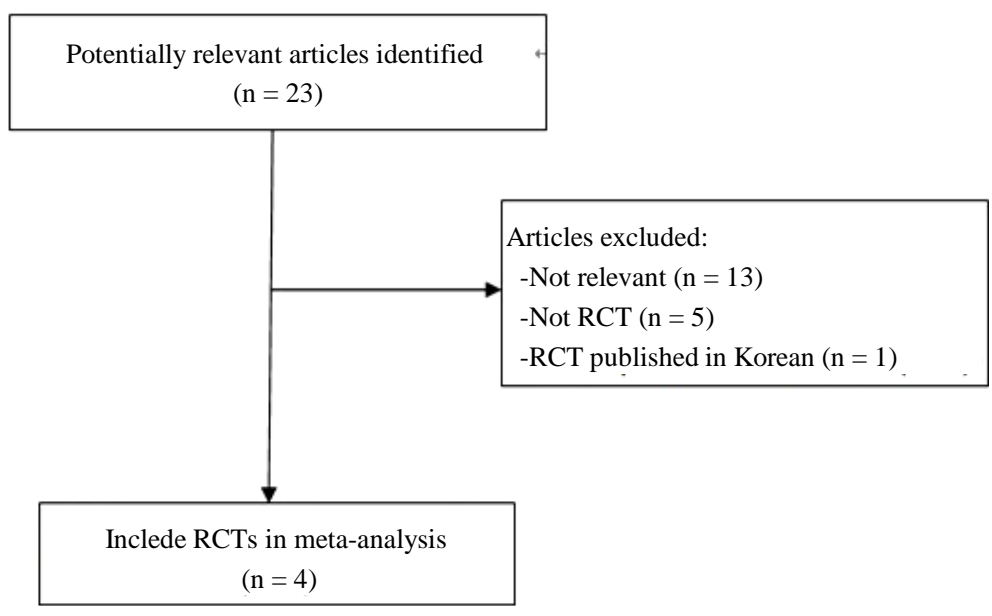

Figure 1. Flow chart of trial selection process. (RCT, Randomized Controlled Trial.)

\begin{tabular}{|c|c|c|c|c|c|}
\hline \multirow[b]{2}{*}{ Study or Subgroup } & \multicolumn{2}{|c|}{ Aromatherapy } & \multicolumn{2}{|c|}{ Control } & \multirow[b]{2}{*}{ Weight } \\
\hline & Events & Total & Events & Total & \\
\hline Burns 2007 & 1 & 251 & 3 & 262 & $47.8 \%$ \\
\hline Calvert 2000 & 3 & 12 & 1 & 10 & $52.2 \%$ \\
\hline Total $(95 \% \mathrm{Cl})$ & & 263 & & 272 & $100.0 \%$ \\
\hline Total events & 4 & & 4 & & \\
\hline \multicolumn{6}{|c|}{$\begin{array}{l}\text { Heterogeneity: } \text { Tau }^{2}=0.72 ; \mathrm{Chi}^{2}=1.58, \mathrm{df}=1(\mathrm{P}=0.21) ; \mathrm{I}^{2}=37 \% \\
\text { Test for overall effect: } Z=0.03(P=0.98)\end{array}$} \\
\hline
\end{tabular}

Risk Ratio Risk Ratio

M-H, Random, $95 \% \mathrm{Cl}$

M-H, Random, 95\% Cl

$0.35[0.04,3.32]$

$2.50[0.31,20.45]$

$0.97[0.14,6.75]$

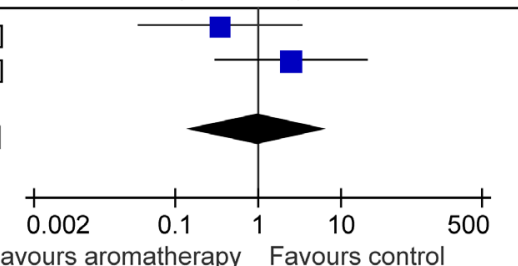

Graph 1. Use of pharmacological analgesia.

\begin{tabular}{|c|c|c|c|c|c|c|c|}
\hline \multirow[b]{2}{*}{ Study or Subgroup } & \multicolumn{2}{|c|}{ Aromatherapy } & \multicolumn{2}{|c|}{ Control } & \multirow[b]{2}{*}{ Weight } & \multirow{2}{*}{$\begin{array}{c}\text { Risk Ratio } \\
\text { M-H, Random, } 95 \% \text { Cl }\end{array}$} & \multirow{2}{*}{$\begin{array}{c}\text { Risk Ratio } \\
\text { M-H, Random, } 95 \% \mathrm{Cl}\end{array}$} \\
\hline & Events & Total & Events & Total & & & \\
\hline Burns 2007 & 224 & 251 & 234 & 262 & $96.7 \%$ & $1.00[0.94,1.06]$ & \\
\hline Calvert 2000 & 10 & 12 & 9 & 10 & $3.3 \%$ & $0.93[0.67,1.28]$ & \\
\hline Total $(95 \% \mathrm{Cl})$ & & 263 & & 272 & $100.0 \%$ & $1.00[0.94,1.06]$ & \\
\hline Total events & 234 & & 243 & & & & \\
\hline \multicolumn{7}{|c|}{ Heterogeneity: $\operatorname{Tau}^{2}=0.00 ; \mathrm{Chi}^{2}=0.20, \mathrm{df}=1(\mathrm{P}=0.65) ; \mathrm{I}^{2}=0 \%$} & 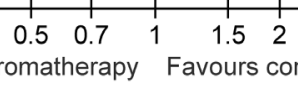 \\
\hline
\end{tabular}

Graph 2. Spontaneous vaginal delivery.

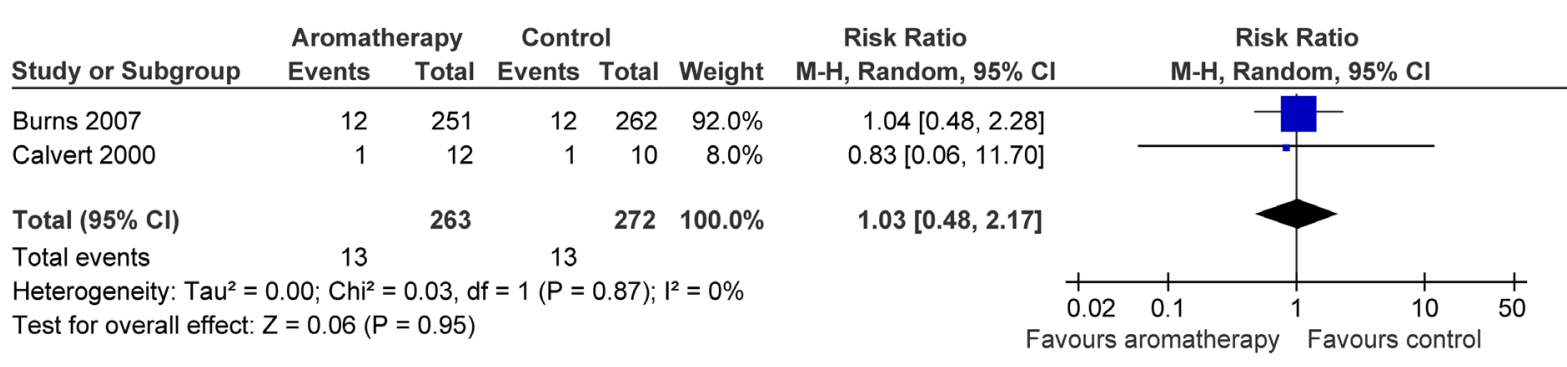

Graph 3. Assisted vaginal birth.

ducing the length of labor and pain intensity during labor, there were no statistically significant effects in other physical-related delivery outcomes such as the rates of spontaneous vaginal delivery and assisted vaginal birth.

Like most systematic reviews and meta-analyses, selective publishing and reporting bias are well-documented so that the positive effects of aromatherapy interventions may be overestimated. Of these 4 trials, only one trial had relatively large sample size. Future large scale research in aromatherapy with laboring women is recom- 


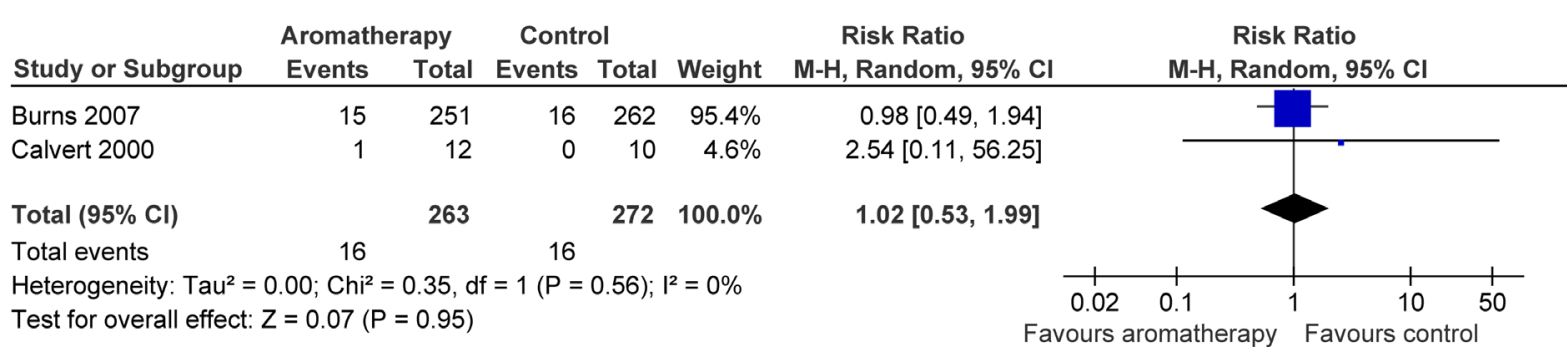

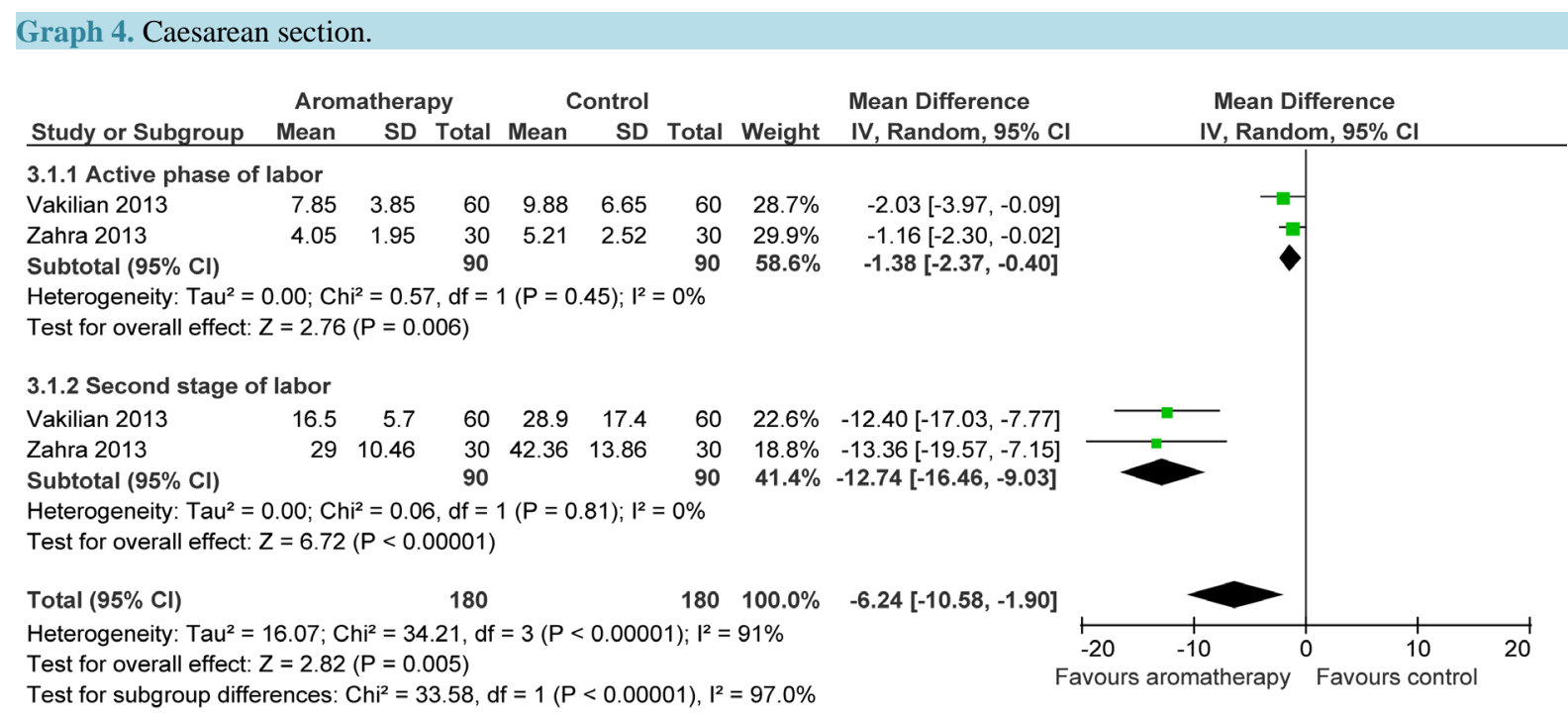

Graph 5. Length of labor.

mended. Although only trial reported positive findings for the use of aromatherapy in satisfaction of childbirth experience with laboring women, other studies examined the effect of aromatherapy for anxiety and depression for postpartum women and found positive findings with minimal risk for the use of aromatherapy as a complementary therapy [13]. Future research should assess the effect of aromatherapy on both anxiety and depression levels among laboring women.

\section{Conclusion}

In conclusion, there was an increase of RCTs published in the use of aromatherapy for laboring women. Due to the existing limited number of studies, the evidence is not sufficiently convincing that aromatherapy is an effective therapy for laboring women.

\section{Acknowledgements}

This study was partially funded by Bureau of Traditional Chinese Medicine of Guangdong Province, China (Research Project Fund No. 20132200). [2013 年广东省中医药局科研项目《CAM 在缓解产妇临产后痛觉感 受及负性情绪的应用效能分析》, 项目编号: 20132200].

\section{References}

[1] Smith, C.A., Collins, C.T. and Crowther, C.A. (2011) Aromatherapy for Pain Management in Labor. Cochrane Database of Systematic Reviews, 7, Article ID: CD009215. http://dx.doi.org/10.1002/14651858.CD009215

[2] Hajiamini, Z., Masoud, S.N., Ebadi, A., Mahboubh, A. and Matin, A.A. (2012) Comparing the Effects of Ice Massage and Acupressure on Labor Pain Reduction. Complementary Therapies in Clinical Practice, 18, 169-172. http://dx.doi.org/10.1016/j.ctcp.2012.05.003

[3] MacKenzie, I.Z., Xu, J., Cusick, C., Midwinter-Morten, H., Meacher, H., Mollison, J. and Brock, M. (2011) Acupuncture for Pain Relief during Induced Labour in Nulliparae: A Randomized Controlled Study. BJOG: An International 
Journal of Obstetrics \& Gynaecology, 118, 440-447. http://dx.doi.org/10.1111/j.1471-0528.2010.02825.x

[4] Tiran, D. (2010) Aromatherapy in Midwifery: Benefits and Risks. Complementary Therapies in Nursing \& Midwifery, 2, 88-92. http://dx.doi.org/10.1016/S1353-6117(96)80081-3

[5] Vakilian, K., Atarha, M., Bekhradi, R. and Chaman, R. (2011) Healing Advantages of Lavender Essential Oil during Episiotomy Recovery: A Clinical Trial. Complementary Therapies in Clinical Practice, 17, 50-53. http://dx.doi.org/10.1016/j.ctcp.2010.05.006

[6] Buckle, J. (2003) Clinical Aromatherapy. Churchill Livingstone, Philadephia.

[7] Simkin, P. and Bolding, A. (2004) Update on Nonpharmacological Approaches to Relieve Labor Pain and Prevent Suffering. Journal of Midwifery \& Women's Health, 49, 489-504. http://dx.doi.org/10.1016/j.jmwh.2004.07.007

[8] Burns, E., Zobbi, V., Panzeri, D., Oskrochi, R. and Regalia, A. (2007) Aromatherapy in Childbirth: A Pilot Randomised Controlled Trial. British Journal of Obsetrics and Gynaecology, 114, 838-844. http://dx.doi.org/10.1111/j.1471-0528.2007.01381.x

[9] Calvert, I. (2000) The Evaluation of the Use of Herbal Substances in the Bath Water of Labouring Women. Personal Communication 2000.

[10] Vakilian, K. and Keramat, A. (2013) The Effects of the Breathing Techniques with and without Aromatherapy on the Length of the Active Phase and Second Stage of Labor. Nursing and Midwifery Studies, 1, 115-119. http://dx.doi.org/10.5812/nms.9886

[11] Zahra, A. and Leila, M.S. (2013) Lavender Aromatherapy Massages in Reducing Labor Pain and Reduction of Labor: A Randomized Controlled Trial. African Journal of Pharmacy and Pharmacology, 7, 426-430.

[12] Lee, M.S., Choi, J., Posadzki, P. and Ernst, E. (2012) Aromatherapy for Health Care: An Overview of Systematic Reviews. Maturitas, 71, 257-260. http://dx.doi.org/10.1016/j.maturitas.2011.12.018

[13] Conrad, P. and Adams, C. (2012) The Effects of Clinical Aromatherapy for Anxiety and Depression in the High Risk Postpartum Woman-A Pilot Study. Complementary Therapies in Clinical Practice, 18, 164-168.

http://dx.doi.org/10.1016/j.ctcp.2012.05.002 